Portland State University

PDXScholar

6-16-2021

\title{
The Community Case for Violence: Toward a Materialist Perspective on Community Work
}

Aven Handley-Merk

Portland State University

Follow this and additional works at: https://pdxscholar.library.pdx.edu/honorstheses

Part of the Civic and Community Engagement Commons, and the Urban Studies and Planning Commons

Let us know how access to this document benefits you.

\section{Recommended Citation}

Handley-Merk, Aven, "The Community Case for Violence: Toward a Materialist Perspective on Community Work" (2021). University Honors Theses. Paper 1043.

https://doi.org/10.15760/honors.1069

This Thesis is brought to you for free and open access. It has been accepted for inclusion in University Honors Theses by an authorized administrator of PDXScholar. Please contact us if we can make this document more accessible: pdxscholar@pdx.edu. 
The Community Case for Violence:

Toward a Materialist Perspective on Community Work

by

Aven Handley-Merk

An undergraduate honors thesis submitted in partial fulfillment of the requirements for the degree of

Bachelor of Arts

in

University Honors

and

Community Development

Thesis Adviser

Lisa K. Bates, PhD

Portland State University 


\section{Table of Contents}

INTRODUCTION

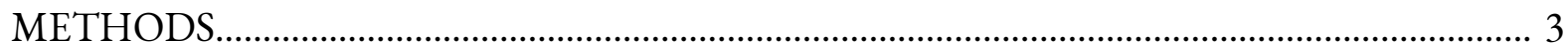

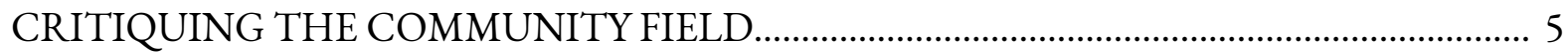

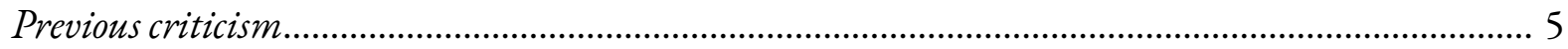

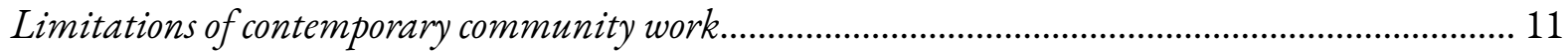

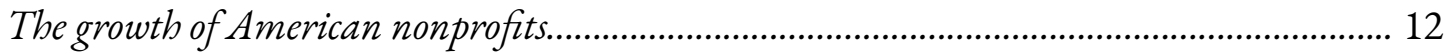

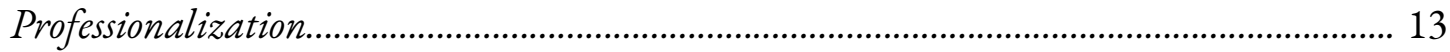

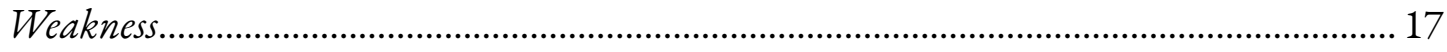

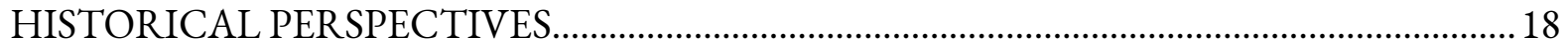

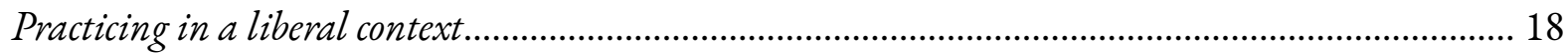

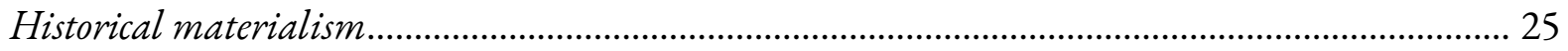

Rioting and looting as material community tactics................................................................ 28

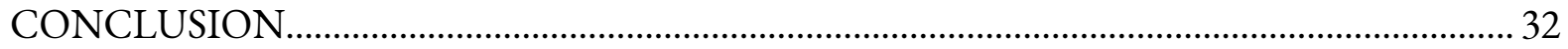

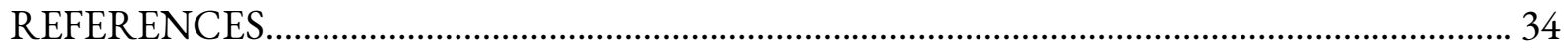




\section{The Community Case for Violence}

Community work is ostensibly concerned with the wellbeing of everyday people. I find it difficult to square this assumption with the conservatism of the community field, and it is from this contradiction that this paper emerges. I think that the problems facing communities in the United States are urgent, and I think that the solutions put forward by the community field are insufficient to solve them. This paper outlines the contours of these beliefs. I explain the structural factors which constrain community work, weakening community organizations and inhibiting most of them from the use of confrontational tactics and the pursuit of radical goals. Having established the limitations of current practices, I suggest two things: (1) that historical materialism may be a useful lens with which to examine community problems, because it reveals broad trends and patterns, and; (2) that rioting and looting might be considered confrontational community tactics which embody a materialist point of view. I briefly examine the efficacy and theoretical underpinnings of this kind of action, and suggest that these are promising tactics to support, if not perform. I end with a broad call for the community field to re-examine its goals and tactics in light of the liberal capitalist context in which it is situated. This paper argues that as long as community work cooperates with the forces imperiling people, the field will be unwilling and unable to advance community health.

\section{Methods}

This paper is somewhat informal. It isn't designed for submission to an academic journal or for exclusively academic audiences, but with wider publication in mind-something between a piece in a publication like The Boston Review and a social theory zine. I've written as clearly and directly as I can, 
only using as much academic convention as necessary to get these ideas across. My intention is to make this paper as readable as possible, for as general of an audience as possible, because I think for community theory to be meaningful, it should be more than accessible. It should invite people to participate in the process of thinking about liberatory politics, which are everyone's business.

Terms used to denote political identities and initiatives are imprecise and open to interpretation, so a few words on this project's taxonomy: I use the terms "abolitionist," "liberatory," and "radical" interchangeably. In doing so, I mean to communicate the necessity of each word in defining the others (radical tactics must be abolitionist, etcetera). Radical is a term used so widely that its meaning is diluted, and I hesitate to employ it here, but etymologically speaking it is appropriate, as the word's original meaning is originating in the root or ground. In this paper I refer to rooted problems. If the problems are rooted, our strategies must be capable of grasping the roots, so radical applies. But I am mindful of the term's murkiness in contemporary discourse, so to be clear: I understand radical tactics to be opposed to capitalism and liberalism and supportive of emancipatory and abolitionist goals. I contrast radical tactics with progressive ones, which I identify as those which do not challenge liberalism and capitalism but seek to reform them into gentler versions of themselves.

This paper is the culmination of a lot of thinking, some of which happened in academic settings and some of which happened outside them. Some of these thoughts emerge from my lived experience being poor and spending time working and living with other poor people. Some of them are inspired by threads of discourse which aren't necessarily happening in academia (or are at least marginal within it), but occur online and in conversations between organizers and protesters, people who participate in black bloc, online theorists, and so on. Some of them come out of conversations 
that I've had with my friends, who have helped me understand and interrogate many of the ideas discussed here. I've cited my academic sources and I want to cite these too, because together, they have been the core of my education on political philosophy and theory. If I have a grasp on any of these ideas, it's because I have discussed them, questioned them, and gradually deepened my understanding through a collective process of dialogue and conversation.

Theory is generated from practice and community, organizing and actions, conflicting and evolving opinions and interpretations; from critical engagement with history and economy and philosophy; from discussion; from lived experiences; and from a long line of written and oral projects. Any theoretical work which hopes to be relevant must build on and engage with preceding and surrounding ideas, because theory is a collaborative process of understanding things. The idea of the individual political or philosophical thinker is ahistorical; theory is a project we are all working on together, and it always has been. I've attempted to represent this process and philosophy in the formal structure of this work.

\section{Critiquing the community field}

\section{Previous criticism}

This paper is a critique of the current state of community work in the United States.

"Community work" describes a variety of interrelated practices, including community development, community organizing, and a range of other projects undertaken at the community or neighborhood level. For the purposes of this paper, the term refers to projects, initiatives, and actions conceptualized and executed by and for communities, with the intention of bettering things for the communities in 
question. What does "bettering” mean? Whatever the community decides it means. Community work is about the pursuit of community goals, whatever those may be, which is a significant problem with the concept. Although a group of people may be working toward a radical goal (prison abolition) or a reactionary one (the institution of racist housing covenants), community is held to be an unquestioned good by most practitioners and audiences (DeFilippis et al., 2010, p. 12; Sihlongonyane, 2009, p. 136). Any idea that can be so prolifically invoked and widely understood as a good by both the left and right should be examined very closely. Osterweil (2020) calls the word a "floating signifier" and a "moral value," by which she means it's a vague concept rather than a well-defined one, used to gesture toward a moral position (she compares it to "democracy" and "organization") (p. 123). Beyond moral goodness, it's tricky to pin down what exactly community conveys. Little (2002) writes that it's a "slippery" concept (p. 3). Sihlongonyane (2009) calls it an unstable phenomenon, with "its meaning embedded in context” (p. 144). The ambiguous nature of the word provides ample room for interpretation, and accordingly, community work applies to many strategies and covers a lot of practical and ideological ground.

The community field can be conceptualized as a collection of community tactics, projects, organizations, ideological beliefs, et cetera, all of which move together along a political spectrum, not in perfect synchronicity, but in a messy pile, according to the climate of the time. There are exceptions on either ideological side: there is left-leaning community work during conservative times, and right-leaning community work during more progressive times, and at any given moment, there is a spectrum. But generally speaking, the tenor of the work is shaped by its context, and the politics of the time infuse the community field (DeFilippis et al., 2010; Sihlongonyane, 2009). In our present 
moment, this is not good news. Fisher and Shragge (2008) illustrate the situation this way: "A hegemonic devotion to the credo of unbridled capitalism rules the world, spilling over into all facets of life including community organizing,” (p. 12).

In Contesting Community, DeFilippis et al. (2010) outline the history of community action in the United States, beginning in the late 19th century with voluntary associations and the social settlement house movement. Over the following century, industrialization increased urban populations and density, people were segmented into city blocks and neighborhoods, and community efforts assumed a significant role in social and political life (p. 41). The theorists observe a political tide in the field that rolls back and forth across this history, between a "canon" of progressive community work and an "anti-canon" of reactionary and conservative community work. The canon takes place in the years 1900-1920, 1930-1946, and 1960-1975; the anti-canon, the 1920s, the 1950s, and from 1975 on. According to this framework, we are still on the conservative side of things (pp. 43-66). This is a helpful conceptualization, although it does obscure the dialectical relationship that exists between dominant forms of community work and resistance to them. At any given time there is tension and influence that flows in both directions, and each era contains the seeds of the next (p. 43).

This framing of history informs a critical analysis of the ways in which contemporary community action cooperates with neoliberalism, and how that cooperation limits, constrains, and contradicts organizational missions and goals. The book's central argument is that for community efforts to succeed (to support healthy communities, which I will define shortly), they must resist neoliberal capitalism, rather than cooperate with it. Furthermore, they must do so by "maintaining conflict at the core of their activities" (p. 33). 
What might that look like? Fisher and Shragge give the Battle of Seattle as a promising example (2008, p. 12). These protests targeted the 1999 World Trade Organization Ministerial Conference, during which members of the WTO gathered in Seattle to launch a new round of trade negotiations. Opposition to the conference was based in criticism of globalization and featured a controversial series of actions. The controversy arose from the central involvement of anarchist philosophy and anarchist protesters, some of which utilized black bloc: the practice of dressing in black outfits to ensure anonymity while protesting (Antifa might be a more recognizable term). This tactic often accompanies acts of vandalism and property destruction. Not all participants in the Seattle protests employed destructive tactics, but enough of them did, and these acts centered in the primary narrative of events. The black bloc (and some other protesters not in bloc) smashed police cars, threw bottles at officers, and ultimately overwhelmed police forces. The National Guard was activated. Over 500 people were arrested (Oldham, 2009). If this was community work, it was certainly a conflict-oriented kind, which makes it an interesting proposal for the future of the community field.

To understand the reasoning in presenting events in Seattle as a model, it's helpful to think about what motivates this kind of conflict. The motivation depends on the practitioner, because different groups riot for different reasons. This paper is interested in riots performed by groups with liberatory or abolitionist critiques of the state, which narrows things down, but doesn't simplify them. The two groups in mind (and although they are arguably "groups" they are overlapping, loosely organized, and barely affiliated ones) are anarchists and protesters of police brutality. Not everyone in these groups participates in rioting or looting, but this paper is interested in those that do. Why do protesters dress in black and smash things? What's the point of the destruction? Mainstream 
understanding of these actions does not interpret them as tactical but chaotic, and if there is intention, it is malicious.

According to DeLuca and Peeples' (2002) understanding of events, protesters in bloc in Seattle were attacking the material manifestations of corporate power (Nike, Starbucks, and McDonalds were main targets). They were attacking property and defenders of property (the police, who were defending the corporate buildings from damage). In doing so, they were levelling a critique. They recognized corporations as the new dominant global power, “eclipsing the nation-state," (p. 126) and aimed at them. In other words, there was cogent theory behind their actions. Their tactics were in keeping with their understanding of power: that it lies in the material forms of capitalism and corporatism. This kind of protest isn't intended as a display of public opinion, like a nonviolent march. It doesn't cooperate with the government. Protesters who engage in this activity sneer at permitted protests, seeing them as confused and toothless, because the philosophy behind these tactics includes the belief that the government will never voluntarily concede to the masses, not to the extent that the protesters demand. The intention of destructive direct action can be articulated in different ways: to attack capital, or to express the urgency of demands, or to articulate systemic critiques. These are three ways of saying the same thing, but each angle matters. The goals of anarchist groups are difficult to pin down by nature, and some people participate for other reasons: the catharsis of breaking the things they find oppressive, the fun of participating in mass actions, or solidarity with other protesters-but criticism of the state is usually central.

These tactics simultaneously make a critique and broadcast it. DeLuca and Peeples (2002) write about the protests in Seattle as a "competing image event" (p. 127), intended to distract from and 
contrast with the WTO conference. The argument here is that the conference was designed by the Clinton administration with visuals in mind, with the understanding that by the late 1990s, visuals (specifically those on television) were crucial to promoting political ideas. So the protesters provided their own competing political idea, one that framed corporatism and capitalism as things which hurt people and which could be attacked. As I understand it, that's the general idea behind this kind of protest. It is an attempt to make oppressive systems visible, to provide an avenue against them, and to insist upon—not request—change. Disruptive protest visibilizes the existence and possibility of alternative systems, and it broadcasts that message as loudly as it can.

The broadcast is built into the tactics, which attract attention. Violence in Seattle was perpetrated by a small percentage of protesters and decried by the rest of them, including lead organizers, and some peaceful protesters tried to stop acts of destruction. But of course this was not the story that went on the news. The anarchists were front and center, because what they were doing was shocking and threatening, and their actions defined the public understanding of the protest (DeLuca \& Peeples, 2002, p. 138). That pattern repeats whenever there is violence at political actions, because the violence is usually the most interesting thing happening. So images of violence are disseminated. Today our political visuals are spread online more than on television, but the principle remains the same. This is obvious; anyone who was online during the summer of 2020 saw this practice in action. All of this is to say that confrontational protest has a point of view and is not violence for the sake of violence. It is destructive, but it isn't random or irrational, and whether or not you agree with the underlying theory, these actions are informed and directed by political thought and strategy. In citing the Battle of Seattle as a promising model for future community work, Fisher and Shragge 
understand this, and they explicitly call for more conflict in community practice. Observing the creep of neoliberalism into the community sphere, DeFilippis et al. make the same case for oppositional tactics to re-enter the field. Until this happens, community work won't be able to do much good, for many reasons, some of them conceptual, some of them logistical.

\section{Limitations of contemporary community work}

Community work and protest seem to pursue the same goal—very generally: to help vulnerable people. So why isn't community work sufficient on its own? There are a myriad of reasons, but they boil down to a general theme: it is not sufficient because community problems are fundamental to, and inseparable from, our existing systems, and community work as it stands today does not challenge those systems. Take poverty as a very broad example, because when we talk about “community problems” or “urban problems,” we are often talking about consequences and manifestations of wealth inequality and poverty (by poverty I mean the material conditions generated by race, class, ability, and so on). Poverty is baked into, reproduced and deepened by, and necessary for the functioning of the United States' economic system. Necessary because it generates labor; it's the threat that makes people work to the extent and under the conditions to generate profit. Baked into because you can't have eternally increasing growth unless that money is coming from somewhere-and money flows away from the poor, according to Marx's conception of value production, which informs this line of thinking. In this framework, value produced by the working classes is appropriated and drawn upward, away from working people, which places them in increasingly precarious economic 
positions (Marx, 1867/1990, pp. 340-353). There is no profit without poverty, not unless there is some serious redistribution of wealth happening alongside it, and in the United States there is not.

My point is to demonstrate the entrenched nature of these issues. To eliminate poverty in this country would necessitate a significant transformation of its political and economic structures, and since that is not the goal of most contemporary community development efforts, they aren't making much headway on it (I'm joking, not implying that they could accomplish it if they wanted to). Gilmore writes that social-service nonprofits do not solve social problems. Rather they attempt to mitigate them for "persons who are in the throes of abandonment" (2007, p. 45). The dominant forms of community work that are being practiced right now are not going to solve poverty, or homelessness, or environmental racism, or mass imprisonment, or any of the other problems that currently face us. Nor do they seem that interested in trying, or even understanding why they would want to try. Sihlongonyane (2009) writes that contemporary community development (which has assumed dominance in the field, eclipsing community organizing) focuses on middle-class goals and values, rather than the social causes associated with the term in the 1960s (p. 142). The change in focus arises from functional aspects and contextual constraints. I'll explain a few of these, the ones I think are most significant.

\section{The growth of American nonprofits}

Nonprofit organizations have existed in what is now the United States since the mid-17th century, but their massive proliferation happened in the last four decades. This rapid growth occurred in parallel with, and partially as an effect of, the slow dismantling of the country's social welfare system. 
Nonprofits formed to take up the work that the state was no longer doing, both informally (urgent needs remained, so nonprofits formed, or they adjusted their missions toward what had formerly been state work) and formally (through government contracts) (Fisher \& Shragge, 2008, p. 7; Gilmore, 2007, p. 45). This was particularly true in the case of housing, which helps to explain the centrality of housing in contemporary community practice, and why nonprofit organizations have become the suppliers of affordable housing in the United States (DeFilippis et al., 2010, p. 89). Similar, if less total, transformations happened in other areas. As the state withdrew from the work of service provision and began to delegate its work to nonprofit organizations, the community field professionalized and weakened.

\section{Professionalization}

Gilmore (2007) describes the transfer of responsibility for service provision as a process of the state withdrawing from peoples' lives. Government agencies which previously provided direct social services were hollowed out and transformed into "policing bodies" which oversaw service provision rather than administering it. Provision itself was increasingly done by community organizations (pp. 44-45). In practice, this meant that people collecting benefits or participating in welfare programs no longer did those things in interaction with the state. One effect of this change was a slow shift in public conception of the government's responsibility to people. The shift happened for everyone: the public, the government, and the nonprofit organizations. Now, if you had needs, you didn't take them to the state- the state was not accountable to you. If you obtained services through a community organization, you might understand that the organization was doing government work, but you no 
longer interacted with the government itself. To some extent, it had retreated. The retreat helped invisibilize the state, removing it from public consciousness. It became distant and unseen, more difficult to conceptualize or understand, to access. And as the state gradually abandoned people, it shifted in their minds, until it was no longer seen as a provider of services. It was present in peoples' lives in other ways, however. This process was accompanied by the escalation and militarization of policing in the United States, and the dramatic explosion of the country's prison population.

Because nonprofit organizations stepped in for the state, forming a non-governmental system that nonetheless does state work, Wolch calls the nonprofit sector the "shadow state," and that conception persists in theoretical work on the subject (Wolch, 1990, as cited in DeFilippis et al., 2010, p. 91; Gilmore, 2007, p. 45-46; Trudeau, 2008). This is a critical framing, attentive to the significant power imbalance present in the dynamic. DeFilippis et al. write that relationships between organizations and the state are "usually structured in such a way that community organizations are in a position of being responsible for the provision of social services, but not in a position of control over those services" (2010, p. 91). The shadow state may look like the state, but it has none of the state's power.

As community organizations adopted the responsibility of social service provision, the community field formalized and professionalized. Working with the government necessitated the incorporation of community organizations into nonprofits with 501(c)(3) status, a tax classification granted by the Internal Revenue Service. This classification has existed for over a century (it was created in the Revenue Act of 1913), but the rapid growth of 501(c)(3) nonprofits happened in the second half of the 20th century; there were 50,000 such organizations in the United States in 1953, and 
734,000 of them by 1998 (Smith, 2007, p. 7). To obtain this status, organizations must prove to the IRS that they are engaged in "charitable" work, which in many cases means service provision.

These nonprofits receive their funding from foundations. Foundations can be either nonprofit corporations or philanthropic trusts, but in either case, they are entities which hold and dispense wealth, theoretically for charitable purposes. The biggest examples are well-known and enormously influential: the Bill \& Melinda Gates Foundation, the Ford Foundation, the Rockefeller Foundation, and so on. Foundations are often characterized as inherently conservative institutions, given the source of the money inside them and its tax-exempt status. Gilmore (2007) calls it "twice stolen" - amassed exploitatively by industrial tycoons, then stolen again from the public, because it is sheltered from taxation (p. 46). And it is sheltered indefinitely. Foundations are only required to spend $5 \%$ of their total wealth annually, and the rest of the money can remain untouched. To receive tax-deductible foundation grants from these entities, organizations must have 501(c)(3) status. The status also prohibits them from engaging in political advocacy (Smith, 2007, p. 6-7).

Because nonprofits have very few resources available to them, they are dependent on the grants issued by foundations. The grant process is competitive, and organizations must try and outdo each other for funding, which encourages a competitive rather than collaborative atmosphere in the field. The grant process also shapes the political tenor of community work, because the more closely an organization can align with a foundation's mission and funding priorities, the more likely it is that they will obtain funds. This makes sense, but foundations do not traditionally fund radical work. They certainly don't fund confrontational anti-capitalist work, which is often illegal and always controversial. Because of this funding structure, conflict-oriented work goes off the table for most of 
the field, and cooperative work dominates. Nonprofit missions change slightly in pursuit of funding, and the field shifts to the right.

Foundations are currently undergoing a small transformation. Some are choosing to increase the percentage of their money that they spend annually, pushing more of their wealth into circulation and removing it from tax shelter. Some are rebranding, or shifting their missions and funding priorities toward more progressive, and in some cases radical, goals. The Revolution Will Not Be Funded (2007) suggests many interesting ideas about funding strategy, some of which reject foundations entirely, but some of which propose reforming them, or reforming how organizations work with them. I don't mean to discount that area of thought with this point. But I think the general critique stands, since the major players haven't dramatically changed their approach to funding. Moreover, I would argue that for foundations to change to an extent where this critique no longer applied, they would function so differently that calling them "foundations" would no longer make sense.

These combined factors - the withdrawal of the state and the hand-off of service provision to community organizations, the legal formalization that accompanied that process, the way nonprofit funding works - together, these resulted in the professionalization of much of the community field, as organizations adjusted tone and mission in order to work with the government and pursue grants. These forms of interaction with the state and with conservative funding sources came with limitations. Whether or not nonprofits wanted to pursue radical missions, or missions that provided some form of dissent or opposition to the government, that door was closed. The cumulative effect was a rightward shift in the field. With everything flowing in a conservative direction-organizational missions, tactics, culture, programs - it became difficult to understand why a community organization might take an 
oppositional stance toward government. The state and the community field were not in conflict but in cooperation.

\section{Weakness}

This is a general critique of the field. Not all nonprofits and organizations have professionalized, not all of them cooperate with their neoliberal context, and many of them have good ideas, whether their tactics are confrontational or not (the thesis of this paper is not that tactics must be violent to be helpful or worthwhile). DeFilippis et al. give examples, such as ACORN (the Association of Community Organizations for Reform Now) before it dissolved (pp. 134-164). Mutual aid projects, jail support, and an infrastructure of other community efforts arose around the nightly protests in Portland, OR during the summer of 2020. These projects did not engage in confrontational tactics but provided support to those who did, forming a peaceful scaffolding around protesters. This is the tentative suggestion that this paper is making, one path that community organizations might explore, to the extent that they are able.

There are adjustments that might be helpful, short of revolutionary system changes. Theorists often critique the project funding strategy, which is the model by which left-leaning nonprofits are almost always funded. Organizations are granted money on a project-by-project basis, which means that grants are awarded for specific programs or projects, but are not intended and may not be used for

organizational costs. The organization itself is left to operate on a very tight budget, and a great deal of planning and energy must go into keeping it alive. This is a significant factor in the short lifespan of most community organizations (Fisher \& Shragge, 2008, pp. 11-12; Gilmore, 2007, p. 51). 
But even the rare organizations that are not constrained by a relationship to the state, those that are successful in securing adequate funding, and those that are aware of, and able to resist, the conservative atmosphere of the community field—even these are limited in other ways. Community organizations and their employees experience the conditions of neoliberal capitalism, just like the people that they are trying to help. They are subject to economic pressure, they typically have limited resources, and their workers are usually vulnerable. Community work is very rarely lucrative. The more radical the work, the more that tends to be true, and staff are trying to be helpful with very few resources, both personally and on an organizational level (Munshi \& Willse, 2007, p. xviii). The reach of community organizations is limited in large part for this reason. This is why foundations are so influential: organizations really need their money.

\section{Historical perspectives}

\section{Practicing in a liberal context}

As community scholars are fond of saying, the problems facing communities are systemic. This means that they are built into our systems on all levels. This paper is concerned with the macro; so by systems I am referring to capitalism (economic) and liberalism (philosophical). In calling liberalism a philosophical system, I mean that it is a system of thought which informs, undergirds, and justifies political, economic, and social structures and systems-including, of course, those pertaining to the community. Liberalism is the dominant ideology in the West, including the United States. It encompasses both political parties, and both liberal (as it is generally used today, to mean ostensible progressivism) and conservative beliefs. As Bell puts it, "most inhabitants of the West are now conscripts 
of liberalism: the scope of the tradition has expanded to encompass the vast majority of political positions regarded as legitimate" (emphasis original) (2014, p. 689).

There is disagreement on how to define the boundaries of liberal ideology, both because it has evolved over centuries and was never unified to begin with, and because the label was retroactively applied to philosophers and thinkers who did not define themselves as liberals in their time.

Delineating the exact contours of a philosophy is beyond what I can offer here, but I'll give what I understand to be a conventional (if constructed) understanding of liberalism's birth, and the tenets that I think are central and relevant, insofar as this argument is concerned. Bell (2014) writes that "at the turn of the twenty-first century, the dominant narrative views [liberalism] as a product of the mid-seventeenth century or earlier. In the former, the French and American revolutions and the global spread of capitalism play a starring role; in the latter, the Glorious Revolution of 1688 and the religious wars in Europe” (p. 692). Assuming the former, liberalism triumphed in the late 18th century, winning out against the Ancien Régime, belief in absolute monarchy and established religion (Duncan, 2014b). It has been the dominant philosophy in the West ever since, resisting challenges from communism and fascism (Paxton, 2004).

That doesn't mean that there has been no ideological variation over the past two centuries. Unchecked accumulation of capital during the industrial era resulted in a global crisis of capitalism in the 1930s, which in the United States manifested as a severe economic crash and subsequent unrest. Most Western governments mitigated the disaster by softening capitalism's edges. The United States increased regulation on industry and founded its welfare system, marking the beginning of the Keynesian era. The programs and policies of this era mitigated the emergency, but basic political and 
economic structures remained unchanged, which left the reforms vulnerable to rollback-and

predictably, that vulnerability was eventually exploited. The government began to hollow out the new agencies in the 1970s. The neoliberal era is the period of the slow unraveling of the welfare state and simultaneous loosening of industry regulations. Although there is not perfect consensus on the timeline, most theorists agree that this period stretches from the mid 1970s to today (DeFilippis et al., 2010, p. 40; Gilmore, 2007, p. 45; Munshi \& Willse, 2007, p. xv). There isn't total agreement on the meaning of the word, either, but Bell (2014) explains that "since the 1970s [neoliberalism] has served as shorthand for the valorisation of the minimal state and deregulated market” (p. 702), and that is how I understand it here.

It's easy to credit the conservative transformation of community work to the transition from Keynesian liberalism to neoliberalism, because the timeline aligns, and because it's technically true. The transformation of the community field described in the short history above did happen during the period described as neoliberal, and it seems characteristic of that period, since one of the most cited features of neoliberalism is the dismantling of the welfare state. But this is a conclusion drawn from a short historical perspective, one which only considers the last half century in its scope. I think that a persistent focus on neoliberalism allows liberalism to fade from view, slipping from sight and escaping attention. As concerns this paper, liberalism evades blame in (much of) community studies, escaping culpability for problems discussed in the field. Harvey notes that when we talk about neoliberalism as a source of problems, we tend to disappear and absolve capitalism, which is the same basic point (Risager, 2016). 
The implication when we blame neoliberalism is that the neo is the problem, that if we could wind back the clock fifty years, the situation would improve. If that is true, it's only because we would be temporarily undoing a consequence that is all but guaranteed. Neoliberalism is an extremely predictable destination of liberalism. It's the place where liberal society arrives; because when market logic directs society, it will eventually consume most everything else, including the principles which held the market in some degree of check. That process is necessary to maintain perpetually increasing growth: profit must be found in, and pulled from, more and more places. That is not to say that this process is completely mechanical, with no nuance, variation, or human influence, but it is the logical trajectory of liberal philosophy.

Because neoliberalism is a subset of liberalism, the structural differences between the two are a matter of degrees, and their philosophies do not meaningfully differ. Just as neoliberal economics are liberal economics with the safety off, so too is neoliberal philosophy just a heightened version of liberal philosophy, one which has seeped into and infused more and more aspects of life. An often observed aspect of neoliberalism is the commodification of absolutely everything (hobbies, friends, self, soul, etcetera) as profit is wrung from more and more locales. This occurs as market logic is applied in new areas, but the core aspects of the philosophy behind that logic have not changed. Paxton (2004) defines them below, talking about the triumph of liberalism in the late 18th century:

Unlike conservatives, [liberals] accepted the revolution's goals of liberty, equality, and fraternity, but they applied them in ways suitable for an educated middle class. Classical liberals interpreted liberty as individual personal freedom, preferred limited constitutional government and a laissez-faire economy to any kind of state intervention, whether mercantilist, as in the early nineteenth century, or socialist, as 
later on. Equality they understood as opportunity made accessible to talent by education; they accepted inequality of achievement and hence of power and wealth. Fraternity they considered the normal condition of free men (and they tended to regard public affairs as men's business), and therefore in no need of artificial reinforcement, since economic interests were naturally harmonious and the truth would [win] out in a free marketplace of ideas (p. 22).

This is one summation of the core of liberalism. Various scholars have different conceptions of the philosophy (Bell, 2014). But it's a description that I recognize and believe, and it comes from a classical liberal project defining its own values (Liberté, égalité, fraternitê). This definition's resonance suggests that it might be relevant, and its context situates it in the heart of a significant liberal effort, so I think it's a fair definition to use here. I recognize these principles because they persist today. Liberalism and neoliberalism have in common individualism, dominance of the market, and supposed, but more or less imagined, meritocracy. These traits may intensify or weaken depending on the historical moment, but they are core aspects of liberal philosophy. Speaking about the overlap between neoliberal and neoconservative beliefs (both of which fall within the scope of liberalism), Gilmore notes a shared trait: "a frightening willingness to engage in human sacrifice while calling it something else” (2007, p. 44). I suggest that human sacrifice was an aspect of liberalism from the start, due to the necessary presence of capitalism alongside it.

A philosophy of market dominance paired with very little support for social welfare cannot help but undermine communities. There is an unresolvable contradiction between the market and community, which DeFilippis et al. observe and name as a central piece of their book's argument (2010, p. 80). A healthy community exists when a group of people experiences security and resilience, 
when the group is stable and bonded enough that the individuals within it can lean on one another, be supported, recover, and grow, and when the group facilitates and enables accountability between people. Capitalism fragments and mines communities, displacing people, scattering them whenever and wherever is useful for profitability and management of surplus value (Harvey, 2004). It places millions of people in such atomized and perilous positions that it is difficult for them to benefit from social support, let alone provide support to other people. Basic survival—which means labor, work, attempting to afford the things one needs to continue living-consumes time and energy to an extent that building and maintaining relationships becomes difficult. At the same time, capitalism creates structures which don't require a community to function. It is perfectly possible to survive in the United States with a job and no friends.

In short, liberalism isn't for helping everyone. It never was, and it didn't ever purport to be. It has always been a philosophy in which supposedly skill, but in practice class (and to a much lesser extent luck) determines one's life outcomes. Economic mobility is not really experienced by poor Americans, but supposing that it was, millions of people would still be left in poverty, suffering for the crime of not being skilled enough to find a way out of it. That is the implication of meritocracy: if success is something that is earned, that means you have to earn it, and those that don't manage to do so deserve what they get. Liberalism is not a philosophy which supports healthy communities, because it is the opposite of secure. It encourages and justifies precarity, a state in which one must work to stay alive. Survival is always in question.

I don't see this understanding represented in the community field. It's not that theorists don't critique capitalism and its effects on communities, but I don't often see the real urgency or scope of the 
problems being discussed, their fundamental and systemic nature. We often say that they are "rooted." That doesn't just mean that problems are deep or difficult to solve. It means that they are inherently wound up in our systems (social, economic, political), and that they cannot be unrooted without very serious critical engagement with those systems, and in my view, considering the depth of the problems, the dismantling and replacement of those systems. These discussions are not central, but they should be. A full conversation is necessary, because of the volume and level of suffering in question, and because of the rate at which we can expect things to worsen, given (if nothing else) the accelerating climate crisis.

Liberalism makes it hard to see things in these terms. One aspect of liberal culture is a sort of post-history perspective, one which is currently being challenged by dramatic circumstances but is persistent and gives real resistance to understanding or contextualizing-in some cases even remembering-events. Lowe identifies an "economy of affirmation and forgetting that characterizes liberal humanist understanding," (2015, p. 39) by which she means that liberal humanism (her wording) swallows, absolves, and erases its own contradictions and horrors. Its stability rests on its ability to do so. Forgotten acts include "the dispossession of indigenous peoples and the settler logics of appropriation, forced removal, and assimilation that are repeated in contemporary land seizures, militarized counter-insurgency at home and abroad, and varieties of nationalism in our present moment," as well as neoliberal trade practices (2015, p. 38). I suggest that this forgetting is evident in our discussion of community problems and tactics. The severity of our current situation slips again and again from mind. To see clearly, other lenses might be applied, ones which make it easier to critically examine systems. I think that a materialist view might be helpful. 


\section{Historical materialism}

Benjamin (1969) explains bistorical materialism as an alternative method to what he calls

bistoricism, which he explains as flattened history, history that has been reduced to a consistent, empty, equalized flow of information, all of which bears the same weight. Time becomes "homogeneous, empty" (264). As he puts it, "historicism gives the 'eternal image' of the past; historical materialism supplies a unique experience with the past” (emphasis added) (p. 262). This framework approaches history as the dynamic process of struggle between classes, a process in which the present is an active part. Paxton (2004) describes it this way: "Marxists, fascism’s first victims, were accustomed to thinking of history as the grand unfolding of deep processes through the clash of economic systems” (p. 8). Historical materialism comes originally from Marx and is a core aspect of Marxist thought (Schecter, 2007, p. 11).

Historicism is accompanied by the concept of progress, the notion that at the end of this uniform slog of history is improvement, that things generally trend for the best and will continue to do so, that we are forever moving toward slightly improved and more enlightened times. These imagined times are essentially the same as our own, just a bit better. Arendt (1970) explains the idea, which she identifies as unknown prior to the 17 th century and "an almost universally accepted dogma" by the 19th, as "the reassuring idea that we need only march into the future, which we cannot help doing anyhow, in order to find a better world." She continues: "Progress gives an answer to that troublesome question. And what shall we do now? The answer, on the lowest level, says: Let us develop what we have into something better, greater, et cetera.” (p. 25). Benjamin describes progress as a storm that 
pushes the angel of history forward into a future to which his back is turned, "while the pile of debris before him grows skyward" (1969, p. 258).

I don't think that perspectives which imagine futures are necessarily bad. They seem essential, actually, since abolitionists imagine futures too. If anything, the problem is that there is not enough imagination in the thinking that Arendt outlines above. Belief in progress is not imaginative, because the only reality that you can conjure up is the one already in front of you. By presenting itself as a final and enlightened worldview, liberalism constricts the imagination rather than expanding it.

Abolitionists can imagine revolutionary futures because of their perspectives on the present and the past, because they reject historicism and embrace the bigger picture. They practice the kind of history that I'm defending here.

The most troubling implication of progress is the notion that we have things basically right, and that our situation will improve if we just continue what we're doing with some minor adjustments along the way. Osterweil explains how historical understanding works against this notion of progress, writing that "studying history also has a vital abolitionist role. Ideology would have us believe that capitalism, the nation-state, the police, prisons, and other violent forms of oppression are timeless, infinite facts" (p. 18). She argues that understanding the recent origins of these structures enables us to envision a world beyond them. History contextualizes, and historical materialism does so particularly well. It helps us see history in terms of shapes and trends, as dynamic rather than uniform, not as a forward march of progress but as interactions between classes as they struggle for power. DeFilippis et al. are in agreement here, explaining that they look at the history of community initiatives with a "wide-angle lens" because it "instantly expands understanding of the varied goals, politics, and shapes 
community efforts take" (p. 35). Of course, this perspective is not enough on its own-Duncan, speaking specifically about the French revolution, explains that the Marxist interpretation of things can be satisfying at first glance but fall apart when examined closely (2014a, 3:15). It is just as important to examine the specific circumstances in question. But it's helpful to look at things in broad strokes, and in terms of class relationships (and these things aren't mutually exclusive with details). This view of history is a story of shifting power relations over time, in which we can discern patterns which bear relevance to us: Benjamin's flashing moments of warning and recognition (1969, p. 255). Or, as he writes here:

The tradition of the oppressed teaches us that the 'state of emergency' in which we live is not the exception but the rule. We must attain to a conception of history that is in keeping with this insight. Then we shall clearly realize that it is our task to bring about a real state of emergency, and this will improve our position in the struggle against Fascism (p. 257).

This is still true, including the bit about fascism.

When Imbroscio (2011) calls specifically for Marxist voices in urban studies, I think it's in large part because of this conceptual framing of history. I think that this perspective can help us see liberalism and capitalism—not see them in any particular way, not necessarily morally, but just see them: their attributes and features and patterns of enactment, see that they are a particular philosophy and a particular form of economic organization, but certainly not the only philosophy or form that have ever been used, or the only options available to us. 


\section{Rioting and looting as material community tactics}

I've attempted to demonstrate why current practices are not sufficient for addressing community problems or meaningfully advancing community health, and I've suggested a historical perspective that may help us think about the stakes and our options. What would tactics informed by this perspective look like? There are any number of possibilities, but this paper is specifically concerned with rioting and looting, so I will limit my discussion there. I tentatively suggest that these acts are materialist in nature, in two respects: (1) they embody the materialist understanding of history that I describe above, and; (2) they attack the material forms of capitalism and liberalism.

First, I am arguing that rioting and looting are tactical, which implies an element of deliberation and choice. I think this is a fair implication. Although riots are often characterized as chaotic and random violence, they aren't completely out of control. They consist of individuals making decisions. Piven and Cloward (1979) make this point, writing that:

While [rioters'] rebellion often appears chaotic from the perspective of conventional American politics, or from the perspective of some organizers, it is not chaotic at all; it is structured political behavior. When people riot in the streets, their behavior is socially patterned, and within those patterns, their actions are to some extent deliberate and purposeful (p. 18).

The practice of looting can also be characterized as purposeful action. Osterweil calls it "a radical and powerful tactic for getting to the roots of the system the movement fights against” (2020, p. 104). This is the place where liberal support sometimes evaporates. Rioting might be understood as a justified emotional response to state oppression, but looting is usually interpreted as petty theft divorced from theory: people stealing televisions, not critiquing the government. Osterweil argues that the media 
"makes criminal and moral divisions between certain kinds of Black youth-those who loot (bad) versus those who protest (good)" (p. 8). But as she understands it, "looting is a method of direct redistribution of wealth" (p. 4), because when people loot they are enriching themselves at the cost of whichever business they're robbing — and while it's not always the case, these businesses are more often than not corporations. Osterweil describes the theft as a way to "solve some of the immediate problems of poverty," (p. 4) as well as an act of property destruction; because when something is stolen, it ceases to be a commodity. Thus looting has an inherently anti-capitalist character. The general belief amongst anarchists is that any successful attack of capital is a good one. Stealing from corporations is understood to be a moral act, regardless of the political philosophy motivating you to do it.

According to this theory, rioting and looting are deliberate and purposeful acts, often undertaken intentionally with radical goals in mind, but anti-capitalist even when not accompanied by revolutionary ethos. The intentional character of this description matches DeLuca and Peeples' analysis of events in Seattle. But when one takes a wider perspective, as Piven and Cloward do below and elsewhere, there is only so much deliberation involved in actions which are triggered by massive economic and social forces, beyond any one individual's control:

Our main point, however, is that whatever position one takes on the 'causes' of mass unrest, there is general agreement that extraordinary disturbances in the larger society are required to transform the poor from apathy to hope, from quiescence to indignation (1979, p. 14).

Engels makes the same point, writing that 19th century Marxists believed that "revolutions were not made intentionally or arbitrarily, but that they were always and everywhere the necessary result of 
circumstances entirely independent of the will and guidance of particular parties and whole classes” (1847, as cited in Arendt, 1970, p. 12).

These ideas are not mutually exclusive: the notion that massive social pressure produces uprisings among the poor and oppressed does not preclude individuals among those groups from making choices and acting with intention. Some riots are more planned than others, but all of them (like all of our decisions and identities and experiences) are shaped by forces larger than the individual. They are generated by social patterns, and by economic and political structures beyond the control, if not the influence, of any particular person. With this perspective, the question of whether or not rioters have an explicitly revolutionary ideology seems less important (depending of course on the riot in question. I am writing here about riots performed by the oppressed in response to their subjugation). Historical materialism helps us keep this in mind, because it frames things in terms larger than the individual. Here too it is useful to think of systems and patterns, bringing them to the forefront, making them seen.

This historical view informs the perspective behind Osterweil's work on looting as a purposeful and just act, and it informs the perspective behind the thread of argument defending riots as legitimate political activity. This argument holds riots as both liberatory and effective, and applies to current and historical events, spanning and pre-dating the United States' existence. Of particular relevance is the popular argument applying this line of thought to slave resistance. Sinha centers slave revolts in the history of abolition in the United States, writing that "prominent slave revolts marked the turn toward immediate abolition ... Recent historians have declared black resistance to enslavement 
passé, but it was central to abolition” (2016, p. 2). Osterweil agrees, characterizing mass slave escapes as a blow against the state:

The enslaved freed themselves. They did so with an act of mass looting and strike that shook the regime of white supremacist capitalism to its core: they stole themselves from their masters and, in so doing, abolished a huge percentage of America's wealth, a wealth, according to historian David Roediger, "equal to the combined value of all capital invested in manufacturing, railroads, and banks, as well as all currency in circulation and all federal expenditures” (2020, p. 39).

Sinha frames both slave resistance and the abolitionist movement which arose around it as oppositional to the systems I've discussed here, writing that "if slavery is capitalism, as the currently fashionable historical interpretation has it, the movement to abolish it is, at the very least, its obverse." As for liberalism, she observes that "as radical agitators, [abolitionists] were not so much theorists of liberal democracy as critics of it" (2016, p. 3). In other words, the early abolitionist movement included a critique of liberalism, one with material resistance at its heart. If police brutality and mass imprisonment are the modern continuations of slavery, as is frequently argued, then resistance to the two cannot be untangled, and a line of continuity should be recognized from the early abolition movement in the pre-colonial era to protests against police brutality now (Williams, 2015, pp. 51-87). This line of thought holds that state control of Black people has shifted in appearance but not in character: from slavery to police violence and mass incarceration (where labor is extracted from people). If violent resistance to slavery is understood to be liberatory, it follows that violent resistance to modern forms of control should be too. 
Riots are a form of collective action that express this theoretical view. In doing so, they convey an understanding of liberalism and capitalism as things that exist in material forms, forms which can be identified and targeted as a tactical strategy, bringing them into focus. For these reasons, I think that they're promising, and according to Piven and Cloward, historically that has been the case. They write that, "whatever influence lower-class groups occasionally exert in American politics does not result from organization, but from mass protest and the disruptive consequences of protest” (1979, p. 36). Their main point here-a main point of Poor People's Movements as a whole-is that for any gains to be made, those disruptions must be understood as just and supported by strategies that "escalate the momentum and impact of disruptive protest at each stage of its emergence and evolution” (p. 36). Something to think about when we consider how community organizations might play a role in our present moment.

\section{Conclusion}

In this paper I have attempted to convey the limitations of contemporary community work, arguing that structural constraints make it impossible for community organizations to solve pressing community problems in the United States. The problems nonetheless need solving. With this in mind, it is interesting to think about which kinds of dissent are considered justifiable and which are not, when a historical perspective indicates that more disruptive strategies are the ones that usually work. My aim with this paper is to drag that problem into the light. I have no intention of prescribing tactics to practitioners, nor do I think "riot" is a tactic that can be prescribed, for the reasons explained above. 
Riots arise from material conditions and periods of enormous pressure. They do not occur because people prescribe them instead of other strategies.

So I'm not necessarily advocating for violent action, but I do think engagement with this contradiction would be useful. Most of the work being practiced and advanced by the community field does not challenge the forces which undermine and harm communities, so the problems will persist. These problems include an escalating epidemic of police brutality and murders of Black people, unchecked climate destruction, a crisis of mass imprisonment, labor conditions under which the poor are languishing, etcetera—conditions which are not survivable, in which people and communities are increasingly endangered. I see riots and liberal condemnation of them as a point of access to this problem, a place where the problem is made visible. When dissent begins to meaningfully challenge the forces that erode and shatter communities, becoming potentially effective, it crosses the line and is abandoned, if not condemned and undermined, by law-abiding community practitioners. How do we make sense of that paradox, when the broadest goal of the community field is to meaningfully and materially help people? What does it mean if the most promising tactics available are destructive and illegal?

I'm echoing Imbroscio's call for a challenge to liberalism, specifically in the field of community studies. It is essential that the community field employ a critical lens and a historical view, because we need these things to keep the stakes in sight. If our goal is to support healthy communities, and if the situation is as urgent as it seems - it would be helpful to broaden our perspective and reconsider our strategies. 


\section{References}

Arendt, H. (1970). On violence. Harcourt.

Bell, D. (2014). What is liberalism? Political Theory, 42(6), 682-715.

Benjamin, W. (1969). Theses on the philosophy of history. In Illuminations: Essays and reflections (pp. 253-267). Schocken Books.

DeFilippis, J., Fisher, R., \& Shragge, E. (2010). Contesting community: The limits and potential of local organizing. Rutgers University Press.

DeLuca, D. M. \& Peeples, J. (2002). From public sphere to public screen: democracy, activism, and the "violence" of Seattle. Critical Studies in Media Communication, 19(2), 125-151.

Duncan, M. (Host). (2014, July 4). 3-1-The three estates (No. 43) [Audio podcast episode]. In Revolutions.

Duncan, M. (Host). (2014, July 20). 3-2-The broken regime (No. 44) [Audio podcast episode]. In Revolutions.

Fisher, R. \& Shragge, E. (2008). Challenging community organizing: Facing the 21st century. Journal of Community Practice, 8(3), 1-19.

Gilmore, R. W. (2007). In the shadow of the shadow state. In INCITE!, The revolution will not be funded: Beyond the non-profit industrial complex (pp. 41-52). Duke University Press.

Harvey, D. (2004). The 'new' imperialism: accumulation by dispossession.” Socialist Register, 40, 63-87.

Imbroscio, D. (2011). For a critique of the liberal foundations of American cities. Metropolitics. https://metropolitics.org/For-a-Critique-of-the-Liberal.html

Little, A. (2002). The politics of community: Theory E̊ practice. Edinburgh University Press.

Lowe, L. (2015). The intimacies of four continents. Duke University Press. 
Marx, K. (1990). Capital: A critique of political economy, volume one. Penguin Books. (Original work published 1867)

Munshi, S. \& Willse, C. (2007). Foreward. In INCITE!, The revolution will not be funded: Beyond the non-profit industrial complex (pp. xiii-xxii). Duke University Press.

Oldham, K. (2009, November 13). WTO meeting and protests in Seattle (1999) —Part 2. HistoryLink. https://www.historylink.org/File/9213

Osterweil, V. (2020). In defense of looting: A riotous history of uncivil action. Bold Type Books.

Paxton, R. O. (2004). The anatomy offascism. Alfred A. Knopf.

Piven, F. F., \& Cloward, R. A. (1979). Poor people's movements: Why they succeed, how they fail (Vintage Books ed.). Vintage Books.

Risager, B. S. (2016, August 23). Neoliberalism is a political project: An interview with David Harvey. Jacobin. https://www.jacobinmag.com/2016/07/david-harvey-neoliberalism-capitalism-labor-crisis -resistance/

Schecter, D. (2007). The history of the left from Marx to the present: Theoretical perspectives. Continuum International Publishing Group Inc.

Sihlongonyane, M. F. (2009). 'Community development' as a buzz-word. Development in Practice, 19(2), 136-147.

Sinha, M. (2016). The slave's cause: A history of abolition. Yale University Press.

Smith, A. (2007). Introduction. In INCITE!, The revolution will not be funded: Beyond the non-profit industrial complex (pp. 1-18). Duke University Press.

Trudeau, D. (2008). Toward a relational view of the shadow state. Political Geography, 27(6), 669-690.

Williams, K. (2015). Our enemies in blue: Police and power in America (3rd ed). AK Press. 